J. Bangladesh Acad. Sci., Vol. 40, No. 1, 37-44, 2016

\title{
PREVALENCE OF FUNGI IN DIFFERENT VARIETIES OF CHICKPEA (CICER ARIETINUM L.) SEEDS IN STORAGE
}

SHAMIM SHAMSI* AND AMINA KHATUN

Department of Botany, University of Dhaka, Dhaka-1000, Bangladesh

\begin{abstract}
A total of nine species of fungi were found to be associated with seeds of nine varieties of chickpea. The isolated fungi were Alternaria alternata, Aspergillus flavus, A. niger, A. fumigatus, A. nidulans, Curvularia lunata, Penicillium sp., Rhizopus stolonifer and Trichoderma viride. Association of fungi with chickpea seeds was recorded three times, within a week after harvest, after two and five months of storage. The fungal association varied with duration of storage period. Species of Aspergillus, Penicillium and Rhizopus become predominating fungi with increase of the storage period. The fungal association with seeds of chickpea also affects germination, seedling mortality and seedling height. Germination of BARI chola 6 and 7 were completely inhibited due to prevalence of Rhizopus stolonifer in the seeds examined within seven days of harvest. The total fungal infection in chickpea seeds was highest in BARI chola 8 (168) and lowest in BARI chola 1 (65).
\end{abstract}

Key words: Chickpea seeds, Fungi, Prevalence, Seedling height, Seedling mortality

\section{INTRODUCTION}

Chickpea, Cicer arietinum L. belongs to Fabaceae and it is one of the important pulse crops grown in Bangladesh. It is an important protein rich crop and occupies third position both in production and in acreage in pulse production of Bangladesh (Anon. 1995). Chickpeas serve as an energy and protein source not only in human nutrition but also as animal feed which lead to an increase in egg and milk production.

In the last several years, chickpeas cultivation area and production has sharply declined because of some major constraints (Bakr et al. 2002). Chickpea is invaded by more than 50 diseases reported from different parts of the world (Nene 1980, Fakir 1983). Most of the diseases (more than 30) are caused by fungi. In Bangladesh so far 17 chickpea diseases have been recorded, 12 of which are caused by fungi (Bakr et al. 2007). Out of 12 fungal diseases of chickpea, 4 diseases, namely Botrytis grey mould (BGM), wilt, root rot, blight and collar rot are the major ones (Bakr 1994).

Chickpea seeds in storage, carry a mycoflora of 'field' and 'storage' fungi. Field fungi gradually disappear and storage fungi then predominate. Most of the storage pathogen

\footnotetext{
*Corresponding author: <prof.shamsi@gmail.com>.
} 
species are Penicillium spp., Aspergillus spp. and Rhizopus spp. The storage fungi may cause discoloration of the seeds and germination failure (BARI 1986). These fungi grow vigorously and initiate grain spoilage. These also bring about several undesirable changes making them unfit for consumption and sowing.

Lot of research has been done at home and abroad on chickpea diseases and its control but information on storage mycoflora of chickpea seeds is inadequate (Dwivedi 1989, Lal and Singh 1997, Salam 2004). Considering the importance of this popular pulse crop the present research work was undertaken to search the prevalence of fungi in different chickpea seeds in storage conditions.

\section{MATERIALS AND METHODS}

The present study was carried on storage seeds of chickpea. Seed samples of Barichola 1-9 were collected from Bangladesh Agricultural Research Institute (BARI), Gazipur. Samples were collected after harvesting and placed in clean brown paper bags, labeled properly and preserved at room temperature for subsequent use.

The fungi were isolated from the samples following the Tissue Planting method on PDA medium (CAB 1968) and Blotter method of ISTA (1996). Two hundred seeds of each sample were placed on three layers of moist blotting paper (Whatman No. 1) in Petri plates. The seeds were surface sterilized by dipping in 10\% Chlorox solution for 5 minutes and then washed three times with sterilized water. Seeds were placed in each plate and incubated at $25 \pm 2^{\circ} \mathrm{C}$ for $5-7$ days.

Fungi isolated from seed inocula were transferred to separate PDA plates and PDA slants for further studies and preservation. Identification of the isolates were determined based on morphological characteristics observed under a compound microscope following the standard literatures (Barnett and Hunter 2000, Benoit and Mathur 1970, Booth 1971, Ellis 1971, 1976). Per cent frequency of the occurrence of the fungal isolates was calculated by adopting the following formula (Spurr and Wetly 1972).

$$
\% \text { frequency }=\frac{\text { No. of inocula from which fungal isolates were raised }}{\text { No. of inocula cultured }} \times 100
$$

For the determination of germination, 300 seeds of each sample were taken and placed in 30 PDA plates. Each plate contained 10 seeds. Plates were then incubated at room temperature for 7 days. Seeds producing both plumule and radicle were considered as germinated seeds. Germination was recorded after 7 days. Data were expressed as percentage. 
Seedling mortality was determined after 10 days of incubation following the formula (Anon. 2014).

Mortality percentage of seeds $=\frac{\text { Number of dead seed }}{\text { Number of total germinated seed }} \times 100$

Seedling height of different varieties of chickpea seeds at $7^{\text {th }}$ day was also recorded.

\section{RESULTS AND DISCUSSION}

Nine species of fungi belonging to six genera were found to be associated with seeds of nine varieties (BARI chola 1 - BARI chola 9) of chickpea. The isolated fungi were Alternaria alternata (Fr.) Keissler, Aspergillus flavus Link, A. niger Van Tiegh, A. fumigatus Fresenius, A. nidulans Eidam, Curvularia lunata (Wakker) Boedijn, a species of Penicillium Link, Rhizopus stolonifer (Ehrenb.: Fr.) Vuill and Trichoderma viride Pers, (Figs 1, 2).
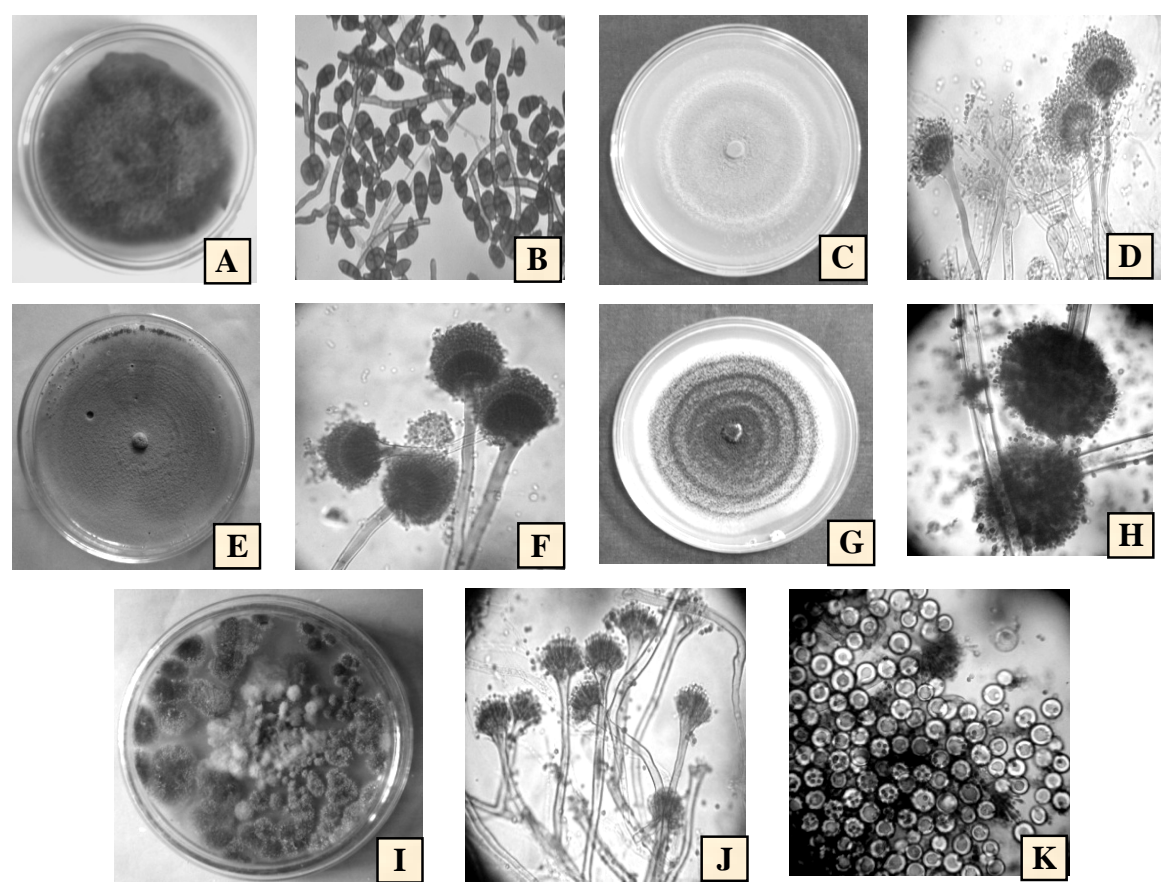

Fig. 1. A: Culture plate and B: Conidiophores and conidia of Alterneria alternata; C: Culture plate and D: Conidiophores and conidia of Aspergillus flavus; E: Culture plate and F: Conidiophores and conidia of A. fumigatus; G: Culture plate and $\mathrm{H}$ : Conidiophores and conidia of $A$. niger; I: Culture plate, J: Conidiophores, conidia and $\mathrm{K}$ : Hulle cell of $A$. nidulans $(\mathrm{Bar}=50 \mu \mathrm{m})$. 

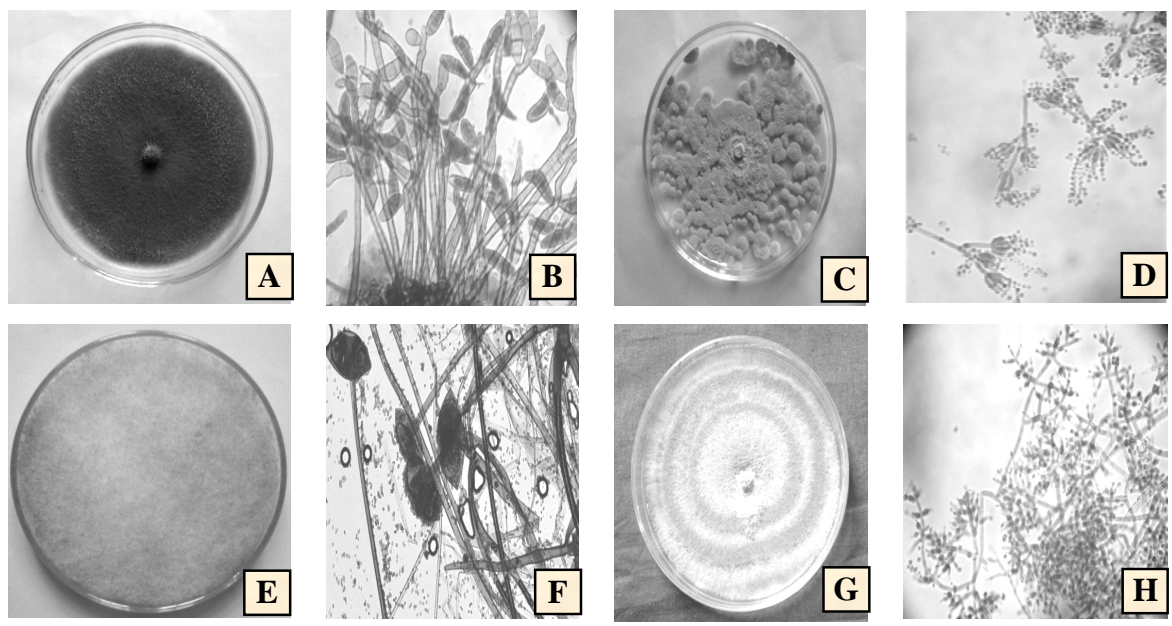

Fig. 2. A: Culture plate, B: Conidiophores and conidia of Curvularia lunata; C: Culture plate, D: Conidiophores and conidia of Penicillium sp.; E: Culture plate, F: Conidiophores and conidia of $R$. stolonifer; G: Culture plate, H: Conidiophores and conidia of Trichoderma viride (Bar $=50 \mu \mathrm{m})$.

Association of fungi with chickpea seeds was recorded three times, within a week after harvest of seeds, after 2 and 5 months of storage. The association of fungi varied with duration of the storage period.

Eight species of fungi belonging to five genera of Deuteromycetes were found to be associated with nine varieties of chickpea seeds. Prevalence of $R$. stolonifer was highest (100\%) in BARI chola 6 and BARI chola 7, whereas prevalence of A. flavus, A. nidulans and Curvularia lunata were lowest (2\%) (Table 1).

Table 1. Frequency percentage of association of fungi with different varieties of chickpea seeds.

\begin{tabular}{lcccccccccc}
\hline \multirow{2}{*}{$\begin{array}{l}\text { Name of } \\
\text { fungi }\end{array}$} & \multicolumn{8}{c}{ Frequency percentage of fungi with chickpea seeds } \\
\cline { 2 - 12 } & BRC & BRC & BRC & BRC & BRC & BRC & BRC & BRC & BRC \\
\cline { 2 - 11 } & 1 & 2 & 3 & 4 & 5 & 6 & 7 & 8 & 9 \\
\hline Alternaria alternata & - & 4 & 3 & 4 & - & - & - & - & - \\
A. fumigatus & 20 & 15 & 28 & 17 & 7 & - & - & & 10 \\
A. niger & 17 & 7 & 43 & 13 & 30 & - & - & 11 & 4 \\
A. nidulans & - & - & 2 & - & - & - & - & - & - \\
Curvularia lunata & - & 2 & - & - & - & - & - & - & - \\
Penicillium sp. & 14 & 8 & 10 & 14 & 3 & - & - & - & - \\
Rhizopus stolonifer & - & 16 & - & 20 & 58 & 100 & 100 & 88 & 57 \\
\hline
\end{tabular}

'-' = No isolate, $\mathrm{BRC}=\mathrm{BARI}$ chola.

Table 2 shows the association of fungi with chickpea seeds after two months of storage. The frequency percentage of $A$. flavus was highest (56\%) in BARI chola 7 and lowest (2\%) with C. lunata, Penicillium sp. and $R$. stolonifer (Table 2). 
Table 3 shows the prevalence of fungi with seeds of chickpea after five months of storage. The frequency percentage of Aspergillus spp., R. stolonifer and Penicillium sp. gradually increased with increase of the storage period. Prevalence of A. flavus was highest $(57 \%)$ in BARI chola 7. Lowest $2 \%$ Penicillium sp. and R. stolonifer was recorded in BARI chola 3 and 5 (Table 3 ).

Table 2. Frequency percentage of association of fungi with different varieties of chickpea seeds after two months of storage.

\begin{tabular}{lccccccccc}
\hline \multirow{2}{*}{$\begin{array}{l}\text { Name of } \\
\text { fungi }\end{array}$} & \multicolumn{8}{c}{ Frequency percentage of fungi with chickpea seeds } \\
\cline { 2 - 12 } & BRC & BRC & BRC & BRC & BRC & BRC & BRC & BRC & BRC \\
\hline & 1 & 2 & 3 & 4 & 5 & 6 & 7 & 8 & 9 \\
\hline Alternaria alternata & - & 18 & 3 & 8 & - & - & - & - & - \\
Aspergillus flavus & 4 & - & - & - & - & - & 56 & 54 & 15 \\
A. fumigatus & 42 & 52 & 22 & 18 & 21 & 19 & 40 & 46 & 24 \\
A. niger & 8 & 4 & 28 & 14 & 3 & 19 & 30 & 32 & 26 \\
Curvularia lunata & - & 2 & - & - & - & 3 & - & - & - \\
Penicillium sp. & 4 & 4 & 2 & 2 & 4 & 5 & - & - & - \\
Rhizopus stolonifer & 14 & - & 14 & 14 & 2 & - & - & 38 & 13 \\
Trichoderma viride & 8 & - & - & 8 & - & - & 8 & 10 & - \\
\hline
\end{tabular}

' - ' = No isolate, $\mathrm{BRC}=\mathrm{BARI}$ chola.

Present result supports the observation of Rodrigues (1984), who isolated 23 fungi from the seeds of chickpea.

Table 3. Frequency percentage of association of fungi with different varieties of chickpea seeds after five months of storage.

\begin{tabular}{lccccccccc}
\hline & \multicolumn{8}{c}{ Frequency percentage of fungi with chickpea seeds } \\
\cline { 2 - 11 } $\begin{array}{l}\text { Name of } \\
\text { fungi }\end{array}$ & BRC & BRC & BRC & BRC & BRC & BRC & BRC & BRC & BRC \\
\cline { 2 - 11 } & 1 & 2 & 3 & 4 & 5 & 6 & 7 & 8 & 9 \\
\hline Alternaria alternata & - & 19 & 3 & 7 & - & - & - & - & - \\
A. flavus & 7 & 4 & - & - & - & - & 57 & 55 & 16 \\
A. fumigatus & 43 & 52 & 23 & 19 & 29 & 20 & 41 & 46 & 25 \\
Aspergillus niger & 9 & 5 & 28 & 14 & 7 & 19 & 30 & 33 & 26 \\
Penicillium sp. & 4 & 6 & 2 & 5 & 4 & 6 & - & - & - \\
Rhizopus stolonifer & 19 & - & 15 & 16 & 2 & - & - & 39 & 12 \\
\hline
\end{tabular}

'-' = No isolate, $\mathrm{BRC}=\mathrm{BARI}$ chola.

Table 4 shows that nine species of fungi were found to be associated with nine varieties of chickpea seeds. Prevalence of A. fumigatus, A. niger, Penicillium sp. and R. stolonifer were highest in all varieties examined and frequency percentage of association of these fungi were also higher, whereas $A$. nidulans was exclusively isolated from BARI chola 3 . The total infection of fungi in chickpea seeds was highest in BARI chola 8 and lowest in BARI chola 1. The frequency percentage of $C$. lunata and A. nidulans were lowest. 
Table 4. Per cent incidence of fungal infection with nine varieties of chickpea seeds.

\begin{tabular}{|c|c|c|c|c|c|c|c|c|c|c|}
\hline \multirow[b]{2}{*}{$\begin{array}{l}\text { Name of } \\
\text { Varieties }\end{array}$} & \multicolumn{10}{|c|}{ Per cent incidence of fungal infection, (Average of three isolations) } \\
\hline & $\begin{array}{c}\text { Alter- } \\
\text { naria } \\
\text { alter- } \\
\text { nata }\end{array}$ & $\begin{array}{l}\text { Asper- } \\
\text { gillus } \\
\text { niger }\end{array}$ & $\begin{array}{c}\text { A. } \\
\text { flavus }\end{array}$ & $\begin{array}{l}\text { A. fumi- } \\
\text { gatus }\end{array}$ & $\begin{array}{l}\text { A. nidu- } \\
\quad \text { lans }\end{array}$ & $\begin{array}{c}\text { Curvu- } \\
\text { laria } \\
\text { lunata }\end{array}$ & $\begin{array}{c}\text { Penici- } \\
\text { llium } \\
\text { sp. }\end{array}$ & $\begin{array}{l}\text { Rhizopus- } \\
\text { stolonifer }\end{array}$ & $\begin{array}{l}\text { Tricho- } \\
\text { derma } \\
\text { sp. }\end{array}$ & $\begin{array}{c}\text { Total } \\
\text { infections }\end{array}$ \\
\hline BRC 1 & - & 9 & 3 & 34 & - & - & 7 & 9 & 3 & 65 \\
\hline BRC 2 & 9 & 4 & 4 & 56 & - & 2 & 4 & 11 & - & 90 \\
\hline BRC 3 & 2 & 28 & - & 35 & 1 & - & 6 & 5 & - & 77 \\
\hline BRC 4 & 4 & 11 & 7 & 14 & - & - & 10 & 32 & 3 & 81 \\
\hline BRC 5 & - & 15 & 3 & 29 & - & - & 7 & 30 & - & 84 \\
\hline BRC 6 & - & 9 & 3 & 13 & - & 1 & 7 & 54 & - & 87 \\
\hline BRC 7 & - & 14 & 21 & 28 & - & - & 6 & 41 & 3 & 113 \\
\hline BRC 8 & - & 26 & 30 & 26 & - & - & 18 & 64 & 4 & 168 \\
\hline BRC 9 & - & 20 & 14 & 16 & - & - & 26 & 34 & - & 110 \\
\hline
\end{tabular}

'-' = No isolate, $\mathrm{BRC}=\mathrm{BARI}$ chola.

The fungal association with seeds of chickpea also effects on germination, seedling mortality as well as seedling height. Germination of BARI chola 6 and 7 was completely inhibited due to prevalence of $R$. stolonifer after 7 days of harvest. The storage mycoflora also affect the seedling mortality and seedling height. Germination percentage of seeds was highest in BARI chola 1 and lowest in BARI chola 9. The percentage of seedling mortality was highest in BARI chola 8 and lowest in BARI chola 1. The length of shoot was highest in BARI chola 1 and lowest in BARI chola 3, whereas root length was highest in BARI chola 1 and lowest in BARI chola 6 (Table 5).

Table 5. Effect of storage mycoflora of chickpea seeds on germination, seedling mortality and seedling height.

\begin{tabular}{|c|c|c|c|c|}
\hline \multirow{2}{*}{$\begin{array}{l}\text { Name of } \\
\text { varieties }\end{array}$} & \multirow{2}{*}{$\begin{array}{c}\text { Germination }(\%) \\
\left(7^{\text {th }} \text { day }\right)\end{array}$} & \multirow{2}{*}{$\begin{array}{l}\text { Mortality (\%) } \\
\text { (after } 7 \text { days) }\end{array}$} & \multicolumn{2}{|c|}{ Seedling height (after 7 days) } \\
\hline & & & Root $(\mathrm{mm})$ & Shoot (mm) \\
\hline BRC 1 & 55 & 22 & 18 & 12 \\
\hline BRC 2 & 36 & 61 & 17 & 10 \\
\hline BRC 3 & 37 & 34 & 13 & 5 \\
\hline BRC 4 & 40 & 39 & 12 & 11 \\
\hline BRC 5 & 25 & 30 & 10 & 4 \\
\hline BRC 6 & 29 & 27 & 4 & 10 \\
\hline BRC 7 & 28 & 35 & 13 & 7 \\
\hline BRC 8 & 45 & 79 & 5 & 10 \\
\hline BRC 9 & 19 & 75 & 9 & 6 \\
\hline
\end{tabular}

$\mathrm{BRC}=\mathrm{BARI}$ chola.

One author (Anon. 1986) reported the association of 5 fungi with chickpea seeds. Aspergillus spp. were the most prevalent fungi. A. flavus and other Aspergillus spp. were commonly associated with stored seed and responsible for reducing germination. 
Dwivedi (1989) recorded A. flavus, A. niger, Fusarium moniliforme and Penicillium oxalicum from chickpea seeds. Lal and Singh (1997) reported that seed mycoflora superficially associated with the freshly collected seeds. Dominant fungal spp. noticed were Alternaria, Aspergillus, Cladosporium, Curvularia and Penicillium in stored seeds. Moreover Aspergillus flavus, A. fumigatus, A. niger and A. luchuensis were dominant in seeds stored for 1 year.

Storage fungi deteriorate the quality and quantity of seeds in storage. Fungal population of nine varieties of chickpea seeds have been extensively studied up to 5 months of storage. Associated fungi were isolated and identified. Association of $A$. nidulans with chickpea seed is new addition to the field of Mycology and Plant Pathology. Present findings will be helpful for designing the management of mycoflora of chickpea in storage.

\section{ACKNOWLEDGEMENTS}

The second author (AK) gratefully acknowledges the financial support by the Ministry of Science and Technology, People's Republic of Bangladesh through NST fellowship.

\section{REFERENCES}

Anonymous. 1986. Annual report (1985-86). Plant Pathology Division, BARI, Joydebpur, Gazipur. pp. 119.

Anonymous. 1995. Krishi Dairy, Agricultural Information Services, Khamarbari, Farmgate, Dhaka.

Anonymous. 2014. International Rules for Seed Testing. International Seed Testing Association, Switzerland. pp. 10.

Bakr, M. A. 1994. Check list of pulse diseases in Bangladesh. Bangladesh Plant Pathology 10(1 \& 2): $10-13$.

Bakr, M.A., K.H.M. Siddique and C. Johansen. 2002. Integrated management of BGM of chickpea in Bangladesh and Australia: Summary of proceedings of a Project Inception Workshop, 1-2 June, 2002, BARI, Bangladesh. pp. 19-32.

Bakr, M.A., H.U. Ahmed, M.A. Ahmed and M.A. Wadud Mian. 2007. Advances in plant pathological research in Bangladesh. Proceed of the National Workshop on "Strategic Intervention on Plant pathological research in Bangladesh". 11-12 February 2007, Plant pathology division. pp. 344.

BARI, 1986. Annual Report 1985/86. Plant Pathology Division, BARI. pp. 119.

Barnett, H.L. and B.B. Hunter. 1972. Illustrated Genera of Imperfect Fungi. Burgess Publishing Company, USA. (Third edn.) pp. 44-45.

Benoit, M.A. and S.B. Mathur. 1970. Identification of species Curvularia on rice seed. Proc. Inst. Seed Test. Assoc. 35(1): 1-23.

Booth, C. 1971. The genus Fusarium. The Commonwealth Mycological Institute, England. pp. 267.

CAB, 1968. Plant Pathologist's Pocket Book. 1st edition. The Commonwealth Mycological Institute, England. pp. 267. 
Dwivedi, S.N. 1989. Effect of fungal invasion on sugars of gram (Cicer arietinum L.). Seed during storage. Indian J. Mycol. and Plant Path. 19(1): 10-13.

Ellis, M.B. 1971. Dematiaceous Hyphomycetes. The Commonwealth Mycological Institute, England. pp. 608.

Ellis, M.B. 1976. More Dematiaceous Hyphomycetes. The Commonwealth Mycological Institute, England. pp. 507.

Fakir, G.A. 1983. Status of research on pulse disease at the Bangladesh Agricultural University (BAU), Mymensingh. Department of Plant Pathology, BAU, Mymensingh. pp.19.

ISTA., 1996. International Rules of Seed Testing Assoc. In: Proc. Int. Seed Test. Assoc. pp. 19-41.

Lal, M.L. and D.B. Singh. 1997. Seed mycoflora of green gram. Madras Agril. J. 84: 11-12.

Nene, Y.L. 1980. Diseases of chickpea. Proceed. International Workshop on Chickpea Improvement. ICRISAT, 28 Feb. 2 Mar. 1979. pp. 171-178.

Rodrigues, E.N. 1984. Identification, incidence, transmission and control of seed borne diseases of some Phillippines legumes. College, Laguna, Philippines. pp. 31-39.

Salam, M.A. 2004. Mycoflora of stored chickpea seeds and their control. MS Thesis, Dept. of Plant Pathology, BAU, Mymensingh. pp. 73.

Spurr, H.W.J. and R.E. Wetly. 1972. Incidence of tobacco leaf microflora in relation to brown spot disease and fungicidal treatment. Phytopathol. 62 : 916-920.

(Received revised manuscript on 6 April, 2016) 